\title{
PENERAPAN PENDEKATAN BRAINSTORMING ROUND ROBIN UNTUK MENINGKATKAN KEMAMPUAN PENALARAN DAN KONEKSI MATEMATIK SERTA KEMANDIRIAN BELAJAR SISWA MTs TERPADU
}

\author{
Maya Siti Rohmah ${ }^{1}$, Indri Herdiman ${ }^{2}$ \\ ${ }^{1}$ Program Studi Pendidikan Matematika, IKIP Siliwangi \\ rohmah@stkipsiliwangi.ac.id \\ ${ }^{2}$ Program Studi Pendidikan Matematika, IKIP Siliwangi \\ herdiman0111@stkipsiliwangi.ac.id
}

\begin{abstract}
This study aims to determine whether the ability of mathematical reasoning, mathematical connections, and self-reliance of integrated MTs students learning using Brainstorming Round Robin approach is better than students using ordinary learning. Is a quasi experimental research with non equivalent pre-test and post-test control group design with sample research the student in one of integrated MTs in West Bandung regency. The instrument used in the form description of the mathematical reasoning and mathematical connection ability and questionnaire of self-reliance. The data obtained is processed by SPSS 22 software. The result show that the achievement and improvement of mathematical reasoning and mathematical connections ability of integrated MTs students learning using Brainstorming Round Robin approach is better than students using ordinary learning. Besides, self-reliance of integrated MTs students learning using Brainstorming Round Robin approach is better than students using ordinary learning.
\end{abstract}

Keywords: Brainstorming Round Robin, mathematical reasoning, mathematical connections, selfreliance

\begin{abstract}
ABSTRAK
Penelitian ini bertujuan untuk mengetahui apakah kemampuan penalaran, koneksi matematik dan kemandirian belajar siswa MTs Terpadu yang menggunakan pembelajaran dengan pendekatan Brainstorming Round Robin lebih baik daripada siswa yang menggunakan pembelajaran biasa. Merupakan penelitian kuasi eksperimen dengan desain non equivalent pre-test and post-test control group design dengan sampel penelitian siswa di salah satu MTs Terpadu di Kabupaten Bandung Barat. Instrumen yang digunakan berupa soal uraian kemampuan penalaran matematik dan koneksi matematik serta angket kemandirian belajar. Data yang diperoleh diolah dengan bantuan software SPSS 22. Hasil menunjukkan bahwa pencapaian dan peningkatan kemampuan penalaran dan koneksi matematik siswa MTs Terpadu yang menggunakan pembelajaran dengan pendekatan Brainstorming Round Robin lebih baik daripada siswa yang menggunakan pembelajaran biasa. Selain itu, pencapaian kemandirian belajar siswa MTs Terpadu yang menggunakan pembelajaran dengan pendekatan Brainstorming Round Robin lebih baik daripada siswa yang menggunakan pembelajaran biasa.
\end{abstract}

Kata Kunci: Brainstorming Round Robin, penalaran matematik, koneksi matematik, kemandirian belajar

\section{PENDAHULUAN}

Pendidikan merupakan salah satu komponen yang sangat penting dalam pembentukan dan pengembangan kualitas Sumber Daya Manusia (SDM) dalam 
menghadapi era globalisasi. Pendidikan matematika merupakan salah satu komponen dari pendidikan nasional yang diajarkan di semua jenjang pendidikan. Kemampuan matematika yang perlu ditingkatkan diantaranya adalah kemampuan penalaran dan koneksi matematik.Ketika siswa mempelajari matematika, salah satu kemampuan yang dilatih adalah penalaran (Rohmah, 2013:11). Kemampuan penalaran penting karena penalaran merupakam alat yang penting untuk matematika dan juga kehidupan sehari-hari (Baroody, 1993). Begitu pun dengan koneksi matematik, yang menghubungkan matematika dengan materi pada pelajaran lain ataupun dalam kehidupan sehari-hari. Sesuai dengan pendapat Kusuma (Nisrina, 2017) yang menyatakan bahwa kemampuan koneksi matematis adalah kemampuan seseorang dalam memperlihatkan hubungan internal dan eksternal matematika, yang meliputi: koneksi antar topik matematika, koneksi dan disiplin ilmu lain, dan koneksi dengan kehidupan sehari-hari. Kemampuan penalaran dan koneksi matematik yang baik diharapkan akan berdampak baik pula terhadap kemampuan sumber daya manusia.

Mengingat pentingnya kemampuan penalaran dan koneksi matematik siswa, pencapaian yang dihasilkan oleh siswa haruslah baik, namun pada kenyataan dilapangan dari hasil wawancara dengan beberapa guru bidang studi matematika yang telah mengajar lebih dari sepuluh tahun menyampaikan bahwa pencapaian hasil dari tes siswa untuk soalsoal penalaran dan koneksi matematik masih tergolong rendah. Hal ini sesuai dengan yang dikemukakan oleh Herdiman (2017) yang menyatakan masih rendahnya kemampuan penalaran matematik siswa SMP yang di dukung oleh nilai hasil tes soal penalaran matematik disekolah.

Pendekatan Brainstorming Round Robin dapat menjadi suatu solusi untuk dapat meningkatkan kemampuan penalaran dan koneksi matematik siswa. Pendekatan Brainstorming Round-Robin ini pada dasarnya adalah Brainstorming (curah pendapat), akan tetapi pada pelaksanaannya setiap anggota kelompok diharuskan untuk memberikan jawaban atau gagasan terhadap permasalahan yang diajukan.(Rohmah, 2013: 6). Pendekatan ini juga dapat mempengaruhi kemandirian belajar siswa, karena dalam pendekatan ini siswa diharuskan mengemukakan pendapatnya secara bergiliran. Hal ini mengharuskan siswa belajar mandiri sebelum pembelajaran di dalam kelas. Sumarmo (Herdiman, 2014) mengungkapkan bahwa kemandirian belajar merupakan proses perancangan dan pemantauan diri yang seksama terhadap proses kognitif dan afektif dalam menyelesaikan suatu tugas akademik. 
Penelitian ini bertujuan untuk menganalisis pencapaian dan peningkatan kemampuan penalaran dan koneksi matematika serta kemandirian belajar siswa MTs Terpadu yang pembelajarannya menggunakan pendekatan Brainstorming Round Robin lebih baik daripada siswa yang menggunakan pembelajaran biasa.

\section{METODOLOGI PENELITIAN}

Penelitian ini menggunakan penelitian kuantitatif yang dilaksanakan pada tahun 2017. Metode dalam penelitian ini adalah metode kuasi eksperimen. Kelas pertama mendapat pembelajaran dengan pendekatan Brainstorming Round-Robin dan kelas kedua mendapat pembelajaran biasa.Pada awal dan akhir pembelajaran diberi tes untuk mengukur kemampuan penalaran dan koneksi matematik. Sehingga desain penelitiannya adalah sebagai berikut (Ruseffendi, 2010):

\section{$\mathrm{O} \times \mathrm{O}$}

$\mathrm{O} \quad \mathrm{O}$

Keterangan:

$\mathrm{O} \quad$ : Pretes $=$ postes (kemampuan penalaran matematik dan koneksi matematik)

X $\quad$ : Pendekatan Brainstorming Round-Robin

: Pengambilan sampel tidak secara acak subyek

Populasi dalam penelitian ini adalah seluruh siswa kelas VII di MTs yang ada di Kabupaten Bandung Barat. Karena keterbatasan waktu, biaya dan tenaga dipilih sampel MTs Terpadu dengan kelas VII B sebagai kelas eksperimen yang mendapat pembelajaran dengan pendekatan Brainstorming Round-Robin dan kelas VII A sebagai kelas kontrol yang mendapat pembelajaran biasa.Instrumen dalam penelitian ini adalah seperangkat soal tes berbentuk uraian yang terdiri dari lima soal kemampuan penalaran matematik dan lima soal kemampuan koneksi matematik. Instrumen yang digunakan dalam penelitian ini berupa pretes (tes awal) dan postes (tes akhir). Agar memiliki validitas isi soal maka soalsoal tersebut dikonsultasikan terlebih dahulu dengan guru kelas di sekolah tempat penelitian. Setelah itu agar memiliki validitas empiris soal-soal tersebut diujicobakan dan kemudian dihitung validitas, reabilitas, daya pembeda, dan indeks kesukarannya. 
Instrumen yang digunakan untuk mengukur pencapaian kemandirian belajar siswa berupa angket yang menggunakan skala Linkert. Skala ini diberikan kepada kedua kelompok sesudah kegiatan penelitian. Sifat pernyataan yang terdapat dalam skala berupa penyataan positif dan pernyataan negatif. Bentuk pernyataan siswa pada soal yang memiliki substansi bersifat positif berupa pernyataan Sangat Setuju (SS; skor $=4)$, Setuju $(S$; skor = 3), Tidak Setuju (TS; skor = 2), dan Sangat Tidak Setuju (STS; skor =1). Sedangkan bentuk pernyataan siswa pada soal yang memiliki substansi bersifat negatif berupa pernyataan Sangat Setuju (SS; skor =1), Setuju (S; skor = 2), Tidak Setuju (TS; skor $=3)$, dan Sangat Tidak Setuju (STS; skor $=4)$.

Cara mengetahui seberapa besar peningkatan penalaran matematik siswa sebelum dan sesudah kegiatan pembelajaran, dilakukan perhitungan gain ternormalisasi dengan rumus dan klasifikasi hasil indeks gain menurut Hake (Herdiman, 2017) sebagai berikut:

$$
\operatorname{Gain}(g)=\frac{\text { Skor akhir }- \text { skor awal }}{\text { SMI }- \text { skor awal }}
$$

Adapun tingkat perolehan skor gain ternormalisasi dikelompokkan kedalam tiga kategori yaitu:

$$
\begin{array}{ll}
0,70<(\mathrm{g}) & : \text { Tinggi } \\
0,30 \leq(\mathrm{g}) \leq 0,70 & : \text { Sedang } \\
0,30>(\mathrm{g}) & : \text { Rendah }
\end{array}
$$

Data hasil dari penelitian ini diolah dengan menggunakan bantuan program software SPSS 22.

\section{HASIL PENELITIAN DAN PEMBAHASAN}

Berdasarkan hasil tes koneksi matematik disajikan rekapitulasi hasil penelitian pada tabel berikut:

Tabel 1. Deskripsi Statistik Hasil Skor Kemampuan Koneksi Matematik

\begin{tabular}{ccccccc}
\hline Statistik & \multicolumn{3}{c}{ Kelas Eksperimen } & \multicolumn{3}{c}{ Kelas Kontrol } \\
\cline { 2 - 7 } & Pretes & Postes & Gain & Pretes & Postes & Gain \\
\hline $\mathbf{N}$ & 44 & 44 & 44 & 40 & 40 & 40 \\
\hline$\overline{\boldsymbol{x}}$ & 7,55 & 14,07 & 0,5498 & 6,30 & 11,22 & 0,3540 \\
\hline
\end{tabular}

Skor Maksimum Ideal (Kemampuan Koneksi Matematik) $=20$

Rekapitulasi untuk hasil tes soal kemempuan penalaran matematik disajikan pada tabel berikut ini : 
Tabel 2. Deskripsi Statistik Hasil Skor Kemampuan Penalaran Masalah Matematik

\begin{tabular}{ccccccc}
\hline Statistik & \multicolumn{3}{c}{ Kelas Eksperimen } & \multicolumn{3}{c}{ Kelas Kontrol } \\
\cline { 2 - 7 } & Pretes & Postes & Gain & Pretes & Postes & Gain \\
\hline $\mathbf{N}$ & 44 & 44 & 44 & 40 & 40 & 40 \\
\hline$\overline{\boldsymbol{x}}$ & 3,27 & 13,02 & 0,8295 & 4,45 & 9,46 & 0,4798 \\
\hline
\end{tabular}

Skor Maksimum Ideal (Kemampuan Penalaran Matematik) $=15$

Pada tabel 1 dan tabel 2, diperlihatkan nilai rata-rata postes dan gain dari kemampuan koneksi dan penalaran matematik kelas eksperimen terlihat secara kasat mata memiliki nilai rata-rata yang lebih tinggi dibandingkan dengan nilai rata-rata untuk kelas kontrol. Dapat dikatakan hal ini menunjukan bahwa pencapaian dan peningkatan kemampuan koneksi dan penalaran matematik siswa kelas eksperimenlebih bik daripada kelas kontrol. Tapi hasil ini harus diolah dan diuji terlebih dahulu secara statistik untuk mendapatkan kesimpulan yang dapat dipercaya.

Nilai hasil penelitian ini diolah menggunakan SPSS 22 dengan hasil rekapitulasi yang disajikan pada tabel berikut:

Tabel 3. Hasil Uji Signifikansi Perbedaan Rata-rata Postes Kemampuan Koneksi Matematik

\begin{tabular}{cccc}
\hline \multirow{2}{*}{ Kelas } & \multicolumn{2}{c}{${\boldsymbol{U j i i ~} \boldsymbol{t}^{\prime}}$} & Kesimpulan \\
\cline { 2 - 3 } & $\mathbf{N}$ & Signifikan & \\
\hline Eksperimen & 44 & 0,001 & $\mathrm{H}_{\mathrm{o}}$ tolak \\
\hline Kontrol & 40 & & \\
\hline
\end{tabular}

Tabel 4. Hasil Uji Signifikansi Perbedaan Rata-rata Postes Kemampuan Penalaran Matematik

\begin{tabular}{cccc}
\hline \multirow{2}{*}{ Kelas } & \multicolumn{2}{c}{ Uji Mann-Whitney } & Kesimpulan \\
\cline { 2 - 3 } & $\mathbf{N}$ & Signifikan & \\
\hline Eksperimen & 44 & 0,000 & $\mathrm{H}_{\mathrm{o}}$ tolak \\
\hline Kontrol & 40 & & \\
\hline
\end{tabular}

Tabel 3 dan Tabel 4 menunjukkan bahwa hasil postes antara kelas eksperimen dan kelas kontrol.kemampuan koneksi matematik dan penalaran matematik secara signifikan lebih baik pada kelas yang menggunakan pembelajaran brainstorming round robin daripada kelas yang menggunakan pembelajaran biasa.

Data gain ternormalisasi yang diperoleh diolah dan hasilnya disajikan pada tabel berikut : 
Tabel 5. Hasil Uji Signifikansi Perbedaan Rata-rata Gain Kemampuan Koneksi Matematik

\begin{tabular}{cccc}
\hline \multirow{2}{*}{ Kelas } & \multicolumn{2}{c}{ Uji Mann-whitney } & \multirow{2}{*}{ Kesimpulan } \\
\cline { 2 - 3 } & $\mathbf{N}$ & Signifikan & \\
\hline Eksperimen & 44 & 0,001 & $\mathrm{H}_{\mathrm{o}}$ tolak \\
\hline Kontrol & 40 & & \\
\hline
\end{tabular}

Tabel 6. Hasil Uji Signifikansi Perbedaan Rata-rata Gain Kemampuan Penalaran Matematik

\begin{tabular}{cccc}
\hline \multirow{2}{*}{ Kelas } & \multicolumn{2}{c}{ Uji Mann-whitney } & Kesimpulan \\
\cline { 2 - 3 } & $\mathbf{N}$ & Signifikan & \\
\hline Eksperimen & 44 & 0,000 & $\mathrm{H}_{\mathrm{o}}$ tolak \\
\hline Kontrol & 40 & & \\
\hline
\end{tabular}

Tabel 5 dan Tabel 6 menunjukkan bahwa nilai gain antara kelas eksperimen dan kelas kontrol. Peningkatan kemampuan koneksi matematik dan penalaran matematik secara signifikan lebih baik pada kelas yang menggunakan pembelajaran brainstorming round robin daripada kelas yang menggunakan pembelajaran biasa.

Tabel 7. Hasil Uji Signifikansi Perbedaan Rata-rata Kemandirian Belajar

\begin{tabular}{cccc}
\hline \multirow{2}{*}{ Kelas } & \multicolumn{2}{c}{ Homogenitas } & Kesimpulan \\
\cline { 2 - 3 } & $\mathbf{N}$ & Signifikan & \\
\hline Eksperimen & 44 & 0,000 & $\mathrm{H}_{\mathrm{o}}$ ditolak \\
\cline { 1 - 2 } Kontrol & 40 & & \\
\hline
\end{tabular}

Tabel 7 menunjukkan bahwa pencapain kemandirian belajar siswa yang menggunakan pembelajaran dengan pendekatan brainstorming round robin lebih baik daripada siswa yang menggunakan pembelajaran biasa.

\section{Kemampuan Koneksi Matematik}

Berdasarkan hasil analisis yang telah dikemukakan sebelumnya, hasil tes awal kemampuan koneksi matematik kelas eksperimen tidak berbeda secara signifikan dibandingkan dengan hasil kemampuan koneksi matematik kelas kontrol.Hal ini menunjukan bahwa tidak terdapat perbedaan kemampuan awal koneksi matematik siswa antara kelas eksperimen dan kelas kontrol.

Setelah kedua kelas diberi perlakuan, kelas eksperimen menggunakan pendekatan brainstorming round-robindan kelas kontrol dengan menggunakan pembelajaran biasa. Diperoleh hasil uji perbedaan dua rata-rata postes menunjukan bahwa nilai kemampuan koneksi yang pembelajarannya menggunakan pendekatan brainstorming round-robinlebih baik daripada yang pembelajarannya menggunakan pembelajaran biasa.Dengan demikian, 
pencapaian kemampuan koneksi matematik siswa untuk kelas eksperimen lebih baik dibandingkan dengan kelas kontrol.

Hasil penelitian perbedaan perlakuan yang diberikan pada masing-masing kelas mengakibatkan peningkatan kemampuan koneksi matematik siswa yang berbeda antara kelas eksperimen dan kelas kontrol. Padahal kemampuan koneksi matematik awal siswa kelas eksperimen dan kelas kontrol tidak terdapat perbedaan yang signifikan. Akan tetapi setelah diberikan perlakuan yang berbeda, pencapaian kemampuan koneksi matematik siswa kelas eksperimen meningkat secara signifikan dibanding kemampuan koneksi matematik kelas kontrol.

Selanjutnya, untuk melihat sejauh mana peningkatan kemampuan koneksi matematik siswa antara kedua kelas dilihat dari gain ternormalisasi. Berdasarkan hasil perhitungan statistik diperoleh peningkatan kemampuan koneksi matematik siswa yang pembelajarannya menggunakan pendekatan brainstorming round-robinlebih baik daripada yang pembelajarannya menggunakan pembelajaran biasa.

\section{Penalaran Matematik}

Berdasarkan hasil analisis yang telah dikemukakan sebelumnya, hasil tes awal kemampuan penalaran matematik kelas eksperimen tidak berbeda secara signifikan dibandingkan dengan hasil kemampuan penalaran matematik kelas kontrol. Hal ini menunjukan bahwa tidak terdapat perbedaan kemampuan awal penalaran matematik siswa antara kelas eksperimen dan kelas kontrol.

Setelah kedua kelas diberi perlakuan, kelas eksperimen menggunakan pendekatan brainstorming round-robindan kelas kontrol dengan menggunakan pembelajaran biasa. Diperoleh hasil uji perbedaan dua rata-rata postes menunjukan bahwa nilai kemampuan penalaran yang pembelajarannya menggunakan pendekatan brainstorming roundrobinlebih baik daripada yang pembelajarannya menggunakan pembelajaran biasa. Dengan demikian, pencapaian kemampuan penalaran matematik siswa untuk kelas eksperimen lebih baik dibandingkan dengan kelas kontrol.

Hasil penelitian perbedaan perlakuan yang diberikan pada masing-masing kelas mengakibatkan peningkatan kemampuan penalaran matematik siswa yang berbeda antara kelas eksperimen dan kelas kontrol. Padahal kemampuan penalaran matematik awal siswa kelas eksperimen dan kelas kontrol tidak terdapat perbedaan yang signifikan. Akan tetapi setelah diberikan perlakuan yang berbeda, pencapaian kemampuan penalaran matematik 
siswa kelas eksperimen meningkat secara signifikan dibanding kemampuan penalaran matematik kelas kontrol.

Selanjutnya, untuk melihat sejauh mana peningkatan kemampuan penalaran matematik siswa antara kedua kelas dilihat dari gain ternormalisasi. Berdasarkan hasil perhitungan statistik diperoleh peningkatan kemampuan penalaran matematik siswa yang pembelajarannya menggunakan pendekatan brainstorming round-robin lebih baik daripada yang pembelajarannya menggunakan pembelajaran biasa.

\section{Kemandirian Belajar}

Kemandirian belajar bisa diartikan sebagai kemauan siswa untuk mempelajari materi pelajaran tanpa bantuan guru atau teman sebayanya. Siswa dapat belajar sendiri dan menemukan solusi dari permasalahan yang dihadapi dalam pelajaran. Berdasarkan hasil analisis data angket kemandirian belajar dengan menggunakan bantuan MSI pada Microsoft excel, didapat kesimpulan bahwa kemandirian siswa yang pembelajarannya menggunakan pendekatan brainstorming round-robin lebih baik daripada yang pembelajarannya menggunakan pembelajaran biasa.

Hal ini dapat terjadi, karena pada pembelajaran dengan menggunakan pendekatan Brainstorming Roun Robin, siswa dituntut untuk bisa mengeluarkan ide-idenya. Oleh karena itu, siswa harus belajar mandiri di rumah. Selain itu pula, pembelajaran ini menuntut siswa untuk mengeluarkan ide-ide kreatifnya, sehingga kemandirian siswa dapat terasah dengan baik.

\section{Implementasi Pembelajaran dengan Pendekatan Brainstorming Round-Robin}

Pada saat di lapangan kegiatan pembelajaran dengan menggunakan pendekatan brainstorming round-robin sangat berbeda dengan yang menggunakan pembelajaran biasa.Pada pertemuan pertama siswa sangat belum terbiasa dengan menggunakan pembelajaran brainstorming round-robin, dimana siswa masih terasa sangat asing dengan soal-soal LKS yang diberikan dan juga ketika siswa dihadapkan dengan soal koneksi matematik dan penalaran matematik secara lisan siswa kurang percaya diri untuk menjawab. Kemudian pada saat mengerjakan LKS yang berisi pertanyaan-pertanyaan brainstorming round-robinsiswa ragu atas jawaban yang ia kerjakan berbeda dengan jawaban yang temannya kerjakandan pada saat pembelajaran siswa kurang aktif. Mereka cenderung masih malu-malu dan juga belum terbiasa persentasi di depan kelas, mereka 
cenderung mengandalkan temannya untuk mempresentasikan hasil kerjanya di depan kelas.

Pada pertemuan kedua, ketiga, dan berikutnya siswa sudah mengalami perkembangan dalam pembelajaran. Siswa sudah memiliki kepercayaan diri dalam mengerjakan LKS dan menjawab pertanyaan-pertanyaan lisan, siswa sudah tidak malumalu untuk persentasi di depan kelas, dan siswa menjadi aktif karena tidak mengandalkan temannya lagi.

\section{KESIMPULAN}

Berdasarkan analisis data dan pembahasan yang dikemukakan sebelumnya, dapat disimpulkan bahwa pencapaian dan peningkatan kemampuan penalaran matematik dan koneksi matematik siswa MTs Terpadu yang pembelajarannya menggunakan pendekatan Brainstorming Round Robin lebih baik daripada siswa yang menggunakan pembelajaran biasa. Begitupun dengan pencapaian kemandirian belajar siswa MTs Terpadu yang pembelajarannya menggunakan pendekatan Brainstorming Round Robin lebih baik daripada siswa yang menggunakan pembelajaran biasa.

\section{REFERENSI}

Baroody, A, J. (1993). Problem Solving, Reasoning, and Communicating, (K-8): Helping Children Think Mathematically. New York: Merrill as imprint of Macmillan Publishing Company.

Herdiman, I. (2014). Penerapan Pendekatan Open-Ended dalam Pembelajaran Matematik untuk Meningkatkan Kemandirian Belajar Siswa. Prosiding Seminar Nasional Pendidikan Matematika. Vol. 2, No. 1.

(2017). Penerapan Pendekatan Open-Ended untuk Meningkatkan Penalaran Matematik Siswa SMP. Jurnal Edukasi dan Sains Matematika. Vol. 3, No. 2.

Kusuma, D.A. (2008). Meningkatkan Kemampuan Koneksi Matematik dengan Menggunakan Pendekatan Konstruktivisme. Tersedia [online]: http://pustaka.inpad.ac.id/wp-contect /uploads/2009/06/meningkatkan-kemampuankoneksi-matematika.pdf. [9 Januari 2013]

Nisrina, N. (2017). Pengaruh Pendekatan Collaborative Problem Solving untuk Meningkatkan Kemampuan Koneksi Matematis Siswa Mts. [online]: publikasi.stkipsiliwangi.ac.id/files/2017/07/NURI-NISRINA-A2-MATEMATIKA13510294.docx. [7 Februari 2017].

Rohmah, M. S. (2013). Pendekatan Brainstorming Teknik Round-Robin untuk Meningkatkan Kemampuan Penalaran, Komunikasi Matematis dan Self-Awareness Siswa SMP.Tesis.Universitas Pendidikan Indonesia. Tidak diterbitkan.

Ruseffendi, E. T. (2010). Dasar-Dasar Penelitian Pendidikan dan Bidang Non-Eksakta Lainnya. Edisi Cetak Pertama. Bandung.: Tarsito. 
Jurnal PRISMA Universitas Suryakancana

Sumarmo, U. (2004). Kemandirian Belajar:Apa, Mengapa, dan Bagaimana Dikembangkan pada Peserta Didik. Laporan Penelitian Hibah Pascasarjana UPI. Bandung : Tidak dipublikasikan. 